\title{
Methane emission by alpaca and sheep fed on lucerne hay or grazed on pastures of perennial ryegrass/white clover or birdsfoot trefoil
}

\author{
C. S. PINARES-PATIÑO ${ }^{1,3}$, M. J. ULYATT ${ }^{1 *}$, G. C. WAGHORN ${ }^{1}$, K. R. LASSEY ${ }^{2}$, \\ T. N. BARRY ${ }^{3}$, C. W. HOLMES ${ }^{3}$ AND D. E. JOHNSON ${ }^{4}$ \\ ${ }^{1}$ AgResearch Limited, Grasslands Research Centre, Tennent Drive, Private Bag 11008, \\ Palmerston North, New Zealand \\ ${ }^{2}$ National Institute of Water and Atmospheric Research Ltd., P.O. Box 14-901, Kilbirnie, \\ Wellington, New Zealand \\ ${ }^{3}$ Institute of Veterinary, Animal and Biomedical Sciences, Massey University, \\ Palmerston North, New Zealand \\ ${ }^{4}$ Metabolic Laboratory, Department of Animal Sciences, Colorado State University, \\ Fort Collins, CO 80523, USA
}

(Revised MS received 20 November 2002)

\begin{abstract}
SUMMARY
Based on the knowledge that alpaca (Lama pacos) have a lower fractional outflow rate of feed particles (particulate FOR) from their forestomach than sheep (San Martin 1987), the current study measured methane $\left(\mathrm{CH}_{4}\right)$ production and other digestion parameters in these species in three successive experiments (1,2 and 3): Experiment 1, lucerne hay fed indoors; Experiment 2, grazed on perennial ryegrass/white clover pasture $(\mathrm{PRG} / \mathrm{WC})$; and Experiment 3, grazed on birdsfoot trefoil (Lotus corniculatus) pasture (Lotus). Six male alpaca and six castrated Romney sheep were simultaneously and successively fed on the forages either ad libitum or at generous herbage allowances (grazing). $\mathrm{CH}_{4}$ production (g/day) (using the sulphur hexafluoride tracer technique), voluntary feed intake (VFI), diet quality, and protozoa counts and volatile fatty acid concentrations in samples of forestomach contents were determined. In addition, feed digestibility, energy and nitrogen (N) balances and microbial $\mathrm{N}$ supply from the forestomach (using purine derivatives excretion) were measured in Experiment 1.

Diets selected by alpaca were of lower quality than those selected by sheep, and the voluntary gross energy intakes (GEI, MJ) per kg of liveweight ${ }^{0 \cdot 75}$ were consistently lower $(P<0 \cdot 001)$ for the alpaca than for the sheep $(0.74 v .1 .36,0.61 v .1 .32$ and $0.77 v .2 .53$ on lucerne hay, PRG/WC and Lotus, respectively). Alpaca and sheep did not differ $(P>0.05)$ in their $\mathrm{CH}_{4}$ yields $(\% \mathrm{GEI})$ when fed on lucerne hay $(5 \cdot 1 v .4 \cdot 7)$, but alpaca had a higher $\mathrm{CH}_{4}$ yield when fed on $\mathrm{PRG} / \mathrm{WC}(9 \cdot 4 v .7 \cdot 5, P<0 \cdot 05)$ and Lotus $(6 \cdot 4$ v. $2 \cdot 7, P<0 \cdot 001)$. When grazing on Lotus, the sheep had very high protozoa counts in their forestomach contents, compared with those with the other forages and those in the alpaca. On lucerne hay and Lotus, but not on PRG/WC, the alpaca had higher $(P<0 \cdot 01)$ acetate/propionate ratio in their forestomach fluid than sheep. When fed on lucerne hay, alpaca and sheep did not differ $(P>0.05)$ in diet $\mathrm{N}$ partition or microbial $\mathrm{N}$ yield, but alpaca had higher $(P<0.05)$ neutral detergent fibre digestibility $(0.478$ v. 0.461$)$ and lower $(P<0.01)$ urinary energy losses $(5.2$ v. 5.8 $\%$ GEI) than sheep. It is suggested that differences between these species in forestomach particulate FOR might have been the underlying physiological mechanism responsible for the differences in $\mathrm{CH}_{4}$ yield, although the between-species differences in VFI and diet quality also had a major effect on it.
\end{abstract}

\footnotetext{
* To whom all correspondence should be addressed. Email: mwu@paradise.net.nz
} 


\section{INTRODUCTION}

Rumen particulate phase fractional outflow rate (particulate FOR) was a major contributor to the differences between individual sheep in methane $\left(\mathrm{CH}_{4}\right)$ yield (percentage of gross energy intake, \% GEI) (Pinares-Patiño et al. 2003). Sheep with lower particulate FOR (i.e. longer retention times) had larger rumen fills and higher fibre digestibilities and $\mathrm{CH}_{4}$ yields. Since the direct measurement of the particulate FOR and rumen fill is much more difficult under grazing conditions than under controlled conditions, the study of $\mathrm{CH}_{4}$ production rates (per unit of intake) by species or breeds differing in these animal factors might reveal further insights into their involvement in $\mathrm{CH}_{4}$ emission.

South American camelids (SAC: llama, Lama glama; alpaca, L. pacos; guanaco, L. guanicoe; and vicuña, $L$. vicugna) differ from sheep in the structure and function of their digestive system and therefore in their nutritional strategies (Vallenas et al. 1971; Heller et al. 1986; San Martin \& Bryant 1989). Most comparative studies, under both penned and grazing conditions, have shown that SAC digest plant cell walls more efficiently than sheep (San Martin \& Bryant 1989; Warmington et al. 1989; Dulphy et al. 1994, 1997; Lemosquet et al. 1996). This higher efficiency was attributed to a lower particulate FOR (San Martin \& Bryant 1989; Dulphy et al. 1994, 1997; Lemosquet et al. 1996; Raggi \& Ferrando 1998).

The study tested the hypothesis that alpaca and sheep, two animal species differing in particulate FOR from their forestomachs, would differ in their $\mathrm{CH}_{4}$ emissions when fed three different forages: (a) lucerne hay fed indoors, (b) grazed perennial ryegrass/white clover pasture (PRG/WC) and (c) grazed birdsfoot trefoil pasture (Lotus).

\section{MATERIALS AND METHODS}

\section{Experimental design}

The study was carried out from October to December 1999 and involved three successive experiments (1, 2 and 3), each using a different forage. In each experiment, six alpaca and six sheep were each fed ad libitum (or generous pasture allowance when grazing) on the same forage at the same time.

Experiment 1 (indoors) was carried out at AgResearch Grasslands, Palmerston North, New Zealand, when chaffed lucerne (Medicago sativa) hay was fed. Experiment 1 comprised 15 days of acclimatization to the diet, followed by a 14-day period (days 1-14) for data and sample collection. Voluntary feed intake (VFI) was measured during the first 6 days of the collection period. Energy and nitrogen $(\mathrm{N})$ balances, $\mathrm{CH}_{4}$ production and microbial $\mathrm{N}$ supply from the forestomach were measured over days 7-12. Forestomach contents were sampled (by stomach tube) for protozoa count and analysis of volatile fatty acids (VFA, mol \%) during the last 2 days of the collection period.

During Experiments 2 and 3 the animals were grazed on perennial ryegrass/white clover (Lolium perenne/Trifolium repens) pasture (hereafter named 'PRG/WC') and birdsfoot trefoil (Lotus corniculatus cv. Grasslands Goldie) pasture (hereafter named 'Lotus'), respectively, at Massey University, Palmerston North, New Zealand. Each of these experiments involved 15 days for acclimatization to the diet, followed by a 6-day period (days 1-6) for data and sample collection. Diet composition, feed intake and $\mathrm{CH}_{4}$ production were measured during the first 4 days, after which, forestomach contents were sampled (by stomach tube) during 2 consecutive days for protozoa count and VFA analysis.

\section{Animals}

Six male alpaca of the Huacaya breed $(61 \cdot 4 \pm 10 \cdot 5 \mathrm{~kg}$; S.D.) and six castrated Romney sheep $(43.0 \pm 1.8 \mathrm{~kg}$; S.D.) were used. At the start of the study, the alpaca were 18 months old and the sheep 15 months old. All animals had been grazing perennial ryegrass/white clover pasture before the commencement of the study.

Each animal was weighed (live weight, LW) at the start and the end of the collection period of each of the experiments.

Environmental conditions within the building during Experiment 1 were not measured. However, outside air maximum and minimum temperatures $\left({ }^{\circ} \mathrm{C}\right)$ and relative humidity (\%) were measured daily throughout the study.

\section{Forages and feeding management}

\section{Experiment 1: Fed indoors on lucerne hay}

During Experiment 1 the animals were housed individually in digestibility crates placed $3 \mathrm{~m}$ from each other within a well-ventilated building. One side of the building was used for alpaca and the other for sheep. The alpaca were housed in crates of similar design to those described by Milne et al. (1978) for red deer, with internal dimensions of $1.72 \mathrm{~m}$ (length), $1.52 \mathrm{~m}$ (height) and $1.11 \mathrm{~m}$ (width). One side of the crate was movable, so the width was decreased to $0.75 \mathrm{~m}$ to prevent the alpaca from turning around. The sheep crates were of standard design. The design of the crates allowed automatic collection of faeces and urine from both species (Pinares-Patiño et al. 2003). Animals were fed ad libitum (allowing 10\% refusal) on chaffed $(\sim 50 \mathrm{~mm})$ lucerne hay. During the balance and forestomach sampling periods feeding level was fixed at 1.05 times the intake of each individual observed during the VFI measurement. The daily ration was fed at $08.00 \mathrm{~h}$ and drinking water was given ad libitum. 
Experiment 2: Grazing on perennial ryegrass/white clover pasture (PRG/WC)

Two 0.4 ha paddocks ( 1 and 2 ) of $P R G / W C$ pasture were selected for uniformity of herbage composition. Each paddock was subdivided into two plots (using a portable fence) and the animal species (alpaca or sheep) randomly allocated to the plots within one paddock. Thus, alpaca and sheep were grazed on paired plots as separate flocks. Within each plot, a fresh strip of pasture was grazed each day. Daily herbage allowance was controlled by electric fences (back and front) to offer 8 and $6 \mathrm{~kg}$ dry matter (DM) per head of alpaca and sheep, respectively. It was assumed that this level of allowance would maximize intake (Hodgson 1990).

Paddock 1 was grazed first, when the forage grasses were flowering. The whole of paddock 1 and one third of paddock 2 were grazed during the acclimatization of experimental animals, while measurements and sample collections were carried out while the animals were grazed in paddock 2 , when the pasture was also in the flowering stage. During the animal measurements, herbage mass was $3490 \pm 346 \mathrm{~kg} \mathrm{DM} / \mathrm{ha}$, composed of perennnial ryegrass $(75 \%)$, white clover (15\%) and other species (10\%; Holcus lanatus, Agrostis capillaris, etc.).

\section{Experiment 3: Grazing on birdsfoot trefoil pasture (Lotus)}

Two paddocks $(0.4$ ha each) of Lotus pasture were weeded manually with the aim of providing a pure stand of this pasture without the use of herbicides, residues of which might affect methanogenesis. The selected paddocks were in the late vegetative stage. There were weeds in either senescent (mostly grasses: perennial ryegrass and annual poa) or vegetative (mostly of the Compositae family) stages. The nongrass weeds were pulled out manually by their roots, but grasses were manually cut $5 \mathrm{~cm}$ above ground level. Weeding took place about 2 days before the animals were due to graze the strip.

After weeding, the total herbage mass was $5680 \pm 437 \mathrm{~kg} \mathrm{DM} / \mathrm{ha}$, of which 53, 42 and $5 \%$ were stems and green leaf of Lotus and senescent weeds (mostly stems of grasses), respectively. The subdivision of paddocks and grazing management were similar to that for the $\mathrm{PRG} / \mathrm{WC}$ pasture (Experiment 2). However, because of the high proportion of stem material, daily pasture allowance was set up on the basis of leaf DM, rather than on whole plant DM.

\section{Measurements and sample collection procedures}

\section{Experiment 1: Fed indoors on lucerne hay}

The total amount of feed required for the whole of the 14-day data and sample collection period was estimated, prepared (chaffed) and after thorough mixing, duplicate samples were taken for DM determination $\left(100{ }^{\circ} \mathrm{C}, 48 \mathrm{~h}\right)$. Another two samples were stored at $-20{ }^{\circ} \mathrm{C}$ for chemical analysis. The amounts of feed refused were recorded daily and samples $(50 \%)$ taken for daily DM determination $\left(100^{\circ} \mathrm{C}\right.$, $48 \mathrm{~h})$. The remaining feed refusals were stored frozen $\left(-20{ }^{\circ} \mathrm{C}\right)$. After the collection, all frozen samples were pooled within animals, mixed thoroughly and re-sampled, then freeze-dried, ground through a 1-mm mesh sieve (Wiley Mill, USA) and used for analyses.

During the energy and $\mathrm{N}$ balance measurement phase (6 days), samples $(10 \%)$ of faeces were taken for daily DM determination $\left(100{ }^{\circ} \mathrm{C}, 48 \mathrm{~h}\right)$. Other daily samples $(10 \%)$ of the faeces were stored frozen $\left(-20{ }^{\circ} \mathrm{C}\right)$ and later pooled within animals, mixed thoroughly, re-sampled, freeze-dried and ground (1-mm mesh sieve) for chemical analysis. Urine from both animal species was acidified at collection as described by Pinares-Patiño et al. (2003) and daily samples $(10 \%)$ were diluted $(1: 3, \mathrm{v} / \mathrm{v})$ in water, subsampled $(20 \%)$ and stored $\left(-20{ }^{\circ} \mathrm{C}\right)$ for later analysis of purine derivatives (PD) on samples pooled within each animal. Other samples $(10 \%)$ of the daily urine production were taken, stored frozen and later pooled within animal, freeze-dried and analysed for energy and $\mathrm{N}$ contents.

Daily $\mathrm{CH}_{4}$ production (g/day) was measured over days $7-10$ by the sulphur hexafluoride $\left(\mathrm{SF}_{6}\right)$ tracer technique (Johnson et al. 1994a) following the procedures described by Pinares-Patiño et al. (2003).

Samples of forestomach contents $(15-20 \mathrm{ml})$ were collected between 2.5 and $3 \cdot 0 \mathrm{~h}$ post feeding on days 13 and 14 and this task took about 2 min per animal. Samples for protozoa counting were prepared using formal-saline solution and following the procedures described by Pinares-Patiño et al. (2003), but using whole (unstrained) forestomach contents. Samples of forestomach contents for VFA analysis were acidified, deproteinized and centrifuged immediately after sampling, using procedures described by Domingue et al. (1991).

\section{Experiments 2 (grazing on $P R G / W C$ ) and 3 (grazing on Lotus)}

Similar methods for collection of samples and their management were used in Experiments 2 and 3 .

Samples of pasture on offer were obtained daily before animals entered the allocated pasture strips. Four (two for each animal species) $0 \cdot 10 \mathrm{~m}^{2}$ quadrats $(0.40 \times 0.25 \mathrm{~m})$ were cut at ground level, weighed, pooled and subsampled for DM determination. Other daily samples of the pooled material were stored $\left(-20^{\circ} \mathrm{C}\right)$ for later within-period pooling, freeze drying, grinding (1-mm mesh) and chemical analysis. 
For each animal species, samples of the grazed herbage were collected from within three $0.5 \mathrm{~m}^{2}$ protected areas (using $1.0 \times 0.5 \mathrm{~m}$ wire cages) by handcutting at the height to which animals had grazed outside the cages and imitating the selective grazing of sward components and plant parts. Daily samples were stored $\left(-20^{\circ} \mathrm{C}\right)$ and later pooled within animal species, freeze dried, ground and used for chemical analysis.

In both Experiments 2 and 3, daily $\mathrm{CH}_{4}$ production (g/day) was measured over days $1-4$ by the $\mathrm{SF}_{6}$ tracer technique following the procedures described by Lassey et al. (1997). A minimum of 3 successful $\mathrm{CH}_{4}$ sampling days was required from each animal.

Total faecal outputs by the grazing animals were collected twice daily using a harness and canvas bag. Collection of faeces was delayed by 1 day relative to the collection of samples for $\mathrm{CH}_{4}$ measurement. Faeces from each animal were weighed, pooled within each day and sampled $(10 \%)$ for DM determination $\left(100{ }^{\circ} \mathrm{C}, 48 \mathrm{~h}\right)$. Other subsamples $(10 \%)$ of the daily faeces output were stored $\left(-20^{\circ} \mathrm{C}\right)$ and later pooled within animal species, subsampled, freeze-dried, ground and used for chemical analysis.

Daily dry matter intakes (DMI) of each individual alpaca and sheep were estimated from the in vitro pasture dry matter digestibilities (DMD) in conjunction with the total faecal DM output by the individual animals.

On days 5 and 6 , samples of forestomach contents were collected within $1 \mathrm{~h}$ after removal from grazing. Collection and management of samples for protozoa count and VFA analysis were carried out as for Experiment 1.

\section{Laboratory methods}

Samples of lucerne chaff (both offered and refused), pastures (both on offer and diets selected), faeces and urine were analysed for gross energy contents (GE, megajoules (MJ)/kg DM) using an adiabatic bomb calorimeter (Gallenkamp Autobomb; Loughborough, Leics, UK) and for total $\mathrm{N}$ by the Kjeldahl method. Organic matter $(\mathrm{OM})$ content of lucerne hay, pasture samples, and faeces was determined by ashing in a furnace at $550{ }^{\circ} \mathrm{C}$ for $16 \mathrm{~h}$, whereas their neutral detergent fibre (NDF) and acid detergent fibre (ADF) contents were determined according to the methods of Goering \& van Soest (1970).

Samples of diet selected on PRG/WC and Lotus pastures were subjected to in vitro digestibility determinations by the enzymatic method of Roughan \& Holland (1977), calibrated using either perennial ryegrass/white clover or birdsfoot trefoil standards with known in vivo digestibility values. Thus, digestibilities of DM (DMD) and OM (OMD) were determined.
Samples of the pastures (PRG/WC and Lotus) on offer and the diet selected were analysed for extractable and bound condensed tannins (CT) using the butanol-HCl procedure of Terrill et al. (1992a).

Urinary purine derivatives (PD), allantoin, xanthine (plus hypoxanthine) and uric acid were respectively determined using the colorimetric, enzymatic and uricase methods of Chen \& Gomes (1992). PD excretion was used to estimate the microbial $\mathrm{N}$ supply from the forestomachs, according to the procedures described by Chen \& Gomes (1992).

VFA concentrations in forestomach fluid were determined by gas chromatography (HRGC 5380, Carlo Erba Instruments, Italy) as described by Hoskin et al. (1995). The molar proportions (mol \%) of acetate, propionate and butyrate, and the acetate/ propionate $(\mathrm{A} / \mathrm{P})$ ratio were calculated. Management of formalin-treated forestomach fluid samples and protozoa counting were carried out as described by Pinares-Patiño et al. (2003). Protozoa counts were expressed per $\mathrm{ml}$ of forestomach contents.

\section{Data calculation and statistical analysis}

For Experiment 1, the VFI and apparent digestibilities of DM, OM, GE, ADF, NDF and $\mathrm{N}$ were determined from the measurements carried out during the VFI and balance periods in conjunction with the chemical composition of samples taken. In Experiments 2 and 3 , these values were determined from the estimated DMI (based on in vitro DMD and faecal DM output) in conjunction with the chemical composition of samples taken. The daily VFI of DM (DMI), GE (GEI) and N (NI) were expressed per kg of $\mathrm{LW}^{0.75}$.

Data for $\mathrm{CH}_{4}$ emission were expressed in three ways: (1) on an absolute basis (per head, g/day), (2) the $\mathrm{CH}_{4}$ energy loss as a percentage of the GEI ( $\% \mathrm{GEI}$ ) and (3) the rate of $\mathrm{CH}_{4}$ production per unit of digestible NDF intake $(\mathrm{g} / \mathrm{kg}$ DNDFI). In this study, the terms ' $\mathrm{CH}_{4}$ production', ' $\mathrm{CH}_{4}$ yield' and ' $\mathrm{CH}_{4}$ emission' are used as described by PinaresPatiño et al. (2003).

In the present study, because the same animals were successively fed on three different forages, time and forage effects were confounded. It was thus not possible to test statistically the effects of forages and the interaction of forages and animal species. However, since the major objective of the study was to compare the two animal species (alpaca and sheep), data were analysed within each experiment (or forage) using Proc GLM of SAS (SAS 1985). Results are presented as the least squared means and standard error of means $( \pm$ S.E. $)$.

Hereafter, the three forages, lucerne hay, PRG/WC and Lotus, will be used in reference to Experiments 1, 2 and 3 , respectively. 
Table 1. Chemical composition $(\mathrm{g} / \mathrm{kg} \mathrm{DM})$ and apparent in vitro organic matter digestibility $(O M D)$ of the forage on offer and of the diet selected by alpaca and sheep during lucerne hay feeding or grazing on perennial ryegrass/white clover pasture (PRG/WC) or birdsfoot trefoil pasture (Lotus)

\begin{tabular}{|c|c|c|c|}
\hline & \multirow[b]{2}{*}{ Forage on offer } & \multicolumn{2}{|c|}{ Diet selected } \\
\hline & & Alpaca & Sheep \\
\hline \multicolumn{4}{|c|}{ Experiment 1: Fed indoors on lucerne hay } \\
\hline Organic matter $(\mathrm{OM})$ & 909 & 912 & 909 \\
\hline Nitrogen $(\mathrm{N})$ & $36 \cdot 5$ & $36 \cdot 7$ & $38 \cdot 3$ \\
\hline Neutral detergent fibre (NDF) & 384 & 394 & 380 \\
\hline Acid detergent fibre (ADF) & 316 & 332 & 313 \\
\hline OM digestibility (OMD) & $0 \cdot 651$ & $0 \cdot 651^{*}$ & $0 \cdot 650^{*}$ \\
\hline \multicolumn{4}{|l|}{ Experiment 2: Grazing on PRG/WC } \\
\hline Organic matter $(\mathrm{OM})$ & 909 & 905 & 898 \\
\hline Nitrogen $(\mathrm{N})$ & 24 & 26 & 38 \\
\hline Neutral detergent fibre (NDF) & 491 & 486 & 360 \\
\hline Acid detergent fibre (ADF) & 300 & 303 & 242 \\
\hline \multicolumn{4}{|l|}{ Condensed tannins (CT) } \\
\hline Extractable & $0 \cdot 52$ & $0 \cdot 62$ & 0.536 \\
\hline Protein-bound & $0 \cdot 36$ & $0 \cdot 17$ & $0 \cdot 269$ \\
\hline Fibre-bound & $0 \cdot 00$ & $0 \cdot 12$ & $0 \cdot 000$ \\
\hline Total CT & $0 \cdot 88$ & $0 \cdot 91$ & $0 \cdot 805$ \\
\hline OM digestibility (OMD) & $0 \cdot 720$ & $0 \cdot 677$ & $0 \cdot 766$ \\
\hline \multicolumn{4}{|l|}{ Experiment 3: Grazing on Lotus } \\
\hline Organic matter $(\mathrm{OM})$ & 926 & 921 & 919 \\
\hline Nitrogen $(\mathrm{N})$ & 28 & 32 & 43 \\
\hline Neutral detergent fibre (NDF) & 422 & 380 & 249 \\
\hline Acid detergent fibre (ADF) & 344 & 282 & 199 \\
\hline \multicolumn{4}{|l|}{ Condensed tannins (CT) } \\
\hline Extractable & $13 \cdot 0$ & $12 \cdot 0$ & $25 \cdot 64$ \\
\hline Protein-bound & $10 \cdot 6$ & $9 \cdot 8$ & $17 \cdot 01$ \\
\hline Fibre-bound & $1 \cdot 8$ & $1 \cdot 7$ & 0.94 \\
\hline Total CT & $25 \cdot 4$ & $23 \cdot 5$ & $43 \cdot 58$ \\
\hline OM digestibility (OMD) & 0.630 & 0.686 & $0 \cdot 800$ \\
\hline
\end{tabular}

* In vivo mean OMD values ( $n=6$ animals).

\section{RESULTS}

\section{Experiment 1: Fed indoors on lucerne hay}

Diet quality, voluntary feed intake (VFI) and apparent digestibility of diet

The composition of the diet eaten by alpaca and sheep is given in Table 1. There were small differences, but statistical comparisons could not be made because only one pooled feed sample was analysed for each animal species.

Alpaca were much heavier $(P<0 \cdot 01)$ than sheep $(63.3 v .43 \cdot 3 \mathrm{~kg})($ Table 2$)$, but they ate significantly $(P<0 \cdot 01)$ less feed than sheep (Table 2). Comparatively (per $\mathrm{kg} \mathrm{LW}^{0.75}$ ), the mean feed intakes of sheep were about twice those of the alpaca.

There were no differences $(P>0 \cdot 05)$ between alpaca and sheep in their apparent digestibilities of DM $(0.636 v .0 .639)$ or OM $(0.651 v .0 .650)$, but alpaca were more efficient $(P<0 \cdot 05)$ than sheep in digesting both NDF $(0.478$ v. 0.461 , s.E. \pm 0.0057$)$ and ADF $(0.526$ v. $0 \cdot 503$, S.E. $\pm 0 \cdot 0058)$.

$\mathrm{CH}_{4}$ emission, forestomach volatile fatty acid ( $\left.\mathrm{VFA}\right)$ proportions and protozoa counts

The $\mathrm{CH}_{4}$ production $(\mathrm{g} /$ day) by alpaca was lower, but not significantly different $(P=0 \cdot 12)$ from that of sheep (Table 2). There was no difference $(P>0.05)$ between the animal species in $\mathrm{CH}_{4}$ yield ( $\left.\% \mathrm{GEI}\right)$ or $\mathrm{CH}_{4}$ production rates per $\mathrm{kg}$ DNDFI (Table 2).

The forestomach fluid of alpaca had higher $(P<0.01)$ acetate/propionate ratio $(\mathrm{A} / \mathrm{P})$ than that of sheep, but the species did not differ $(P>0.05)$ in butyrate concentrations ( $\mathrm{mol} \%)$ in their forestomach fluid (Table 2).

No holotrich protozoa were found in the forestomach contents of alpaca (Table 2), whereas holotrichs accounted for $1.0 \%$ of the total protozoa concentrations in the rumen contents of sheep. Sheep 
Table 2. Liveweight $(L W)$, voluntary feed intake ( VFI, per $\mathrm{kg} \mathrm{LW}^{\mathbf{0} \cdot 75}$ ), $\mathrm{CH}_{4}$ emission, forestomach volatile fatty acid (VFA) proportions and protozoa counts for alpaca and sheep fed indoors on lucerne hay in Experiment $1^{*}$

\begin{tabular}{lccc}
\hline \hline & & & \\
& Alpaca & Sheep & $\begin{array}{c}\text { S.E. } \\
\text { (D.F. }=10)\end{array}$ \\
\hline LW (kg) & $63 \cdot 3$ & $43 \cdot 3$ & $3 \cdot 61$ \\
VFI (per kg LW ${ }^{0} \cdot 75$ & & & \\
$\quad$ DMI (g) & $38 \cdot 8$ & $74 \cdot 0$ & $4 \cdot 20$ \\
$\quad$ GEI (MJ) & $0 \cdot 74$ & $1 \cdot 36$ & $0 \cdot 077$ \\
$\quad$ NI (g) & $1 \cdot 4$ & $2 \cdot 7$ & $0 \cdot 15$ \\
CH emission $\dagger$ & & & \\
g/day & $14 \cdot 9$ & $18 \cdot 8$ & $1 \cdot 70$ \\
$\quad$ \% GEI & $5 \cdot 1$ & $4 \cdot 7$ & $0 \cdot 31$ \\
g/kg DNDFI & $92 \cdot 0$ & $92 \cdot 5$ & $6 \cdot 56$ \\
VFA & & & \\
$\quad$ Acetate/Propionate (A/P) & $3 \cdot 0$ & $2 \cdot 3$ & $0 \cdot 12$ \\
$\quad$ Butyrate (mol \%) & $6 \cdot 9$ & $6 \cdot 5$ & $0 \cdot 66$ \\
Protozoa counts (10 $/ \mathrm{ml})$ & & & \\
$\quad$ Holotrichs & 0 & $0 \cdot 04$ & $0 \cdot 020$ \\
$\quad$ Entodinomorphs & $2 \cdot 08$ & $3 \cdot 80$ & $0 \cdot 381$ \\
$\quad$ Total & $2 \cdot 08$ & $3 \cdot 84$ & $0 \cdot 381$ \\
\hline \hline
\end{tabular}

* Abbreviations: DMI, GEI, NI, DNDFI, are intakes of dry matter, gross energy, nitrogen and digestible neutral detergent fibre, respectively.

$\dagger \mathrm{CH}_{4}$ emission expressed as: (1) $\mathrm{CH}_{4}$ production (g/day), (2) $\mathrm{CH}_{4}$ yield ( $\% \mathrm{GEI}$ ), and (3) rate of $\mathrm{CH}_{4}$ production per kg DNDFI.

Table 3. Energy and nitrogen $(N)$ balances, and microbial $N$ supply from the forestomach for alpaca and sheep fed indoors on lucerne hay in Experiment 1

\begin{tabular}{|c|c|c|c|}
\hline & Alpaca & Sheep & $\begin{array}{c}\text { S.E. } \\
\text { (D.F. }=10)\end{array}$ \\
\hline \multicolumn{4}{|l|}{ Energy balance } \\
\hline Intake $(\mathrm{MJ} / \mathrm{d})$ & $16 \cdot 0$ & $22 \cdot 0$ & $1 \cdot 40$ \\
\hline \multicolumn{4}{|l|}{ Partition ( $\%$ of intake) } \\
\hline Faeces & $37 \cdot 3$ & $38 \cdot 1$ & $0 \cdot 36$ \\
\hline Urine & $5 \cdot 2$ & $5 \cdot 8$ & $0 \cdot 13$ \\
\hline Methane & $5 \cdot 1$ & $4 \cdot 7$ & $0 \cdot 31$ \\
\hline Metabolizable & $52 \cdot 4$ & $51 \cdot 4$ & $0 \cdot 62$ \\
\hline \multicolumn{4}{|l|}{ Nitrogen balance } \\
\hline Intake $\mathrm{g} /$ day & $31 \cdot 2$ & $45 \cdot 1$ & $2 \cdot 81$ \\
\hline \multicolumn{4}{|l|}{ Partition ( $\%$ of intake) } \\
\hline Faeces & $25 \cdot 3$ & $25 \cdot 2$ & $0 \cdot 37$ \\
\hline Urine & $57 \cdot 4$ & $57 \cdot 8$ & $2 \cdot 52$ \\
\hline Retained & $17 \cdot 2$ & $17 \cdot 0$ & $2 \cdot 70$ \\
\hline \multicolumn{4}{|l|}{ Microbial N supply } \\
\hline g/day & $9 \cdot 5$ & $14 \cdot 3$ & $1 \cdot 01$ \\
\hline $\mathrm{g} / \mathrm{kg}$ DOMR* & $29 \cdot 1$ & $31 \cdot 8$ & $2 \cdot 16$ \\
\hline
\end{tabular}

* DOMR, digestible organic matter apparently fermented in the rumen, estimated as 0.65 DOMI, digestible OM intake (Chen \& Gomes 1992). had significantly higher $(P<0 \cdot 01)$ counts $\left(10^{5} / \mathrm{ml}\right)$ of both entodinomorphs and total protozoa than alpaca.

\section{Energy and nitrogen $(N)$ balances and microbial $N$ supply}

The daily energy intake (GEI) by sheep $(22.0 \mathrm{MJ} /$ day $)$ was significantly higher $(P<0 \cdot 01)$ than that of alpaca $(16 \cdot 0 \mathrm{MJ})$ (Table 3). Although the GEI loss as $\mathrm{CH}_{4}$ did not differ between animal species $(4 \cdot 7$ v. $5 \cdot 1 \%$ GEI, for sheep and alpaca, respectively), the urinary energy loss was significantly $(P<0 \cdot 01)$ greater in sheep than in alpaca (Table 3).

The intake of nitrogen $(\mathrm{N}, \mathrm{g} /$ day $)$ by sheep was also significantly $(P<0 \cdot 01)$ higher than that of alpaca (Table 3), but there were no differences $(P>0.05)$ in the $\mathrm{N}$ partitioning between urine and faeces between the animal species.

The daily microbial $\mathrm{N}$ supply was significantly $(P<0 \cdot 01)$ higher in sheep than in alpaca $(14.3 v \cdot 9 \cdot 5 \mathrm{~g} /$ day) (Table 3). Nevertheless, when microbial N supply was expressed per $\mathrm{kg}$ of digestible $\mathrm{OM}$ apparently fermented in the rumen (DOMR), there were no differences $(P>0.05)$ between the animal species.

\section{Experiment 2: Grazing on perennial ryegrass/white clover pasture $(P R G / W C)$}

Diet quality and voluntary feed intake (VFI)

The quality of the PRG/WC diet selected by alpaca was much lower than that selected by sheep (Table 1). For example, the N and NDF contents were lower and higher, respectively, in the diet of alpaca than in the diet of sheep. Accordingly, the OMD of the diet of sheep was higher than that of alpaca (Table 1). As expected the condensed tannin (CT) concentrations in the forage on offer and in the diets selected were low.

Alpaca were much heavier $(P<0.01)$ than sheep (Table 4), but sheep had higher $(P<0 \cdot 001)$ VFI than alpaca (Table 4). For example, per kg LW ${ }^{0.75}$ the GEI (MJ) and NI (g) of sheep were respectively $2 \cdot 2$ and 3 times higher than those of alpaca.

\section{$\mathrm{CH}_{4}$ emission, forestomach volatile fatty acid (VFA) proportions and protozoa counts}

The $\mathrm{CH}_{4}$ production (g/day) by alpaca was lower $(P<0 \cdot 05)$ than that of sheep $(22 \cdot 6 v .31 \cdot 1)$ (Table 4$)$. However, the $\mathrm{CH}_{4}$ yield ( $\% \mathrm{GEI}$ ) of alpaca was higher $(P<0.05)$ than that of sheep. No differences $(P>0.05)$ between the species were found for the $\mathrm{CH}_{4}$ production rates per $\mathrm{kg}$ DNDFI, A/P ratio or butyrate (mol \%) (Table 4).

No holotrich protozoa were found in the forestomach contents of alpaca (Table 4), whereas in sheep holotrichs accounted for less than $1.0 \%$ of the total protozoa counts. Nevertheless, no differences 
Table 4. Liveweight $(L W)$, voluntary feed intake (VFI, per $\mathrm{kg} \mathrm{LW}^{0.75}$ ), $\mathrm{CH}_{4}$ emission, forestomach volatile fatty acid (VFA) proportions and protozoa counts for alpaca and sheep grazing on $P R G / W C$ pasture in Experiment 2*

\begin{tabular}{lccc}
\hline \hline & & & \\
& Alpaca & Sheep & $\begin{array}{c}\text { S.E. } \\
\text { (D.F. }=10)\end{array}$ \\
\hline LW (kg) & $65 \cdot 1$ & $46 \cdot 4$ & $3 \cdot 23$ \\
VFI (per kg LW ${ }^{0.75}$ ) & & & \\
$\quad$ DMI (g) & $33 \cdot 5$ & $69 \cdot 8$ & $3 \cdot 34$ \\
GEI (MJ) & $0 \cdot 61$ & $1 \cdot 32$ & $0 \cdot 063$ \\
NI (g) & $0 \cdot 9$ & $2 \cdot 7$ & $0 \cdot 12$ \\
CH emission $_{\text {g/day }}$ & & & \\
\% GEI & $22 \cdot 6$ & $31 \cdot 1$ & $2 \cdot 26$ \\
g/kg DNDFI & $9 \cdot 4$ & $7 \cdot 5$ & $0 \cdot 81$ \\
VFA & $95 \cdot 2$ & $103 \cdot 1$ & $10 \cdot 17$ \\
$\quad$ Acetate/propionate (A/P) & $2 \cdot 7$ & $2 \cdot 9$ & $0 \cdot 12$ \\
Butyrate (mol \%) & $12 \cdot 0$ & $11 \cdot 0$ & $0 \cdot 74$ \\
Protozoa counts $\left(10^{5} / \mathrm{ml}\right)$ & & & \\
$\quad$ Holotrichs & 0 & $0 \cdot 04$ & $0 \cdot 020$ \\
$\quad$ Entodinomorphs & $4 \cdot 20$ & $4 \cdot 05$ & $0 \cdot 841$ \\
Total & $4 \cdot 20$ & $4 \cdot 09$ & $0 \cdot 843$ \\
\hline \hline
\end{tabular}

* Abbreviations and $\mathrm{CH}_{4}$ emission are the same as in Table 2.

Table 5. Liveweight $(L W)$, voluntary feed intake (VFI, per $\mathrm{kg} \mathrm{LW^{0.75 }}$ ), $\mathrm{CH}_{4}$ emission, forestomach volatile fatty acid (VFA) proportions and protozoa counts for alpaca and sheep grazing Lotus pasture in Experiment 3*

\begin{tabular}{lccc}
\hline \hline & & & \\
& Alpaca & Sheep & $\begin{array}{c}\text { S.E. } \\
\text { (D.F. }=10)\end{array}$ \\
\hline LW (kg) & $63 \cdot 2$ & $47 \cdot 2$ & $3 \cdot 17$ \\
VFI (per kg LW $\left.{ }^{0 \cdot 75}\right)$ & & & \\
$\quad$ DMI (g) & $40 \cdot 3$ & $127 \cdot 9$ & $5 \cdot 55$ \\
GEI (MJ) & $0 \cdot 77$ & $2 \cdot 53$ & $0 \cdot 109$ \\
NI (g) & $1 \cdot 3$ & $5 \cdot 5$ & $0 \cdot 23$ \\
CH emission $_{\text {g/day }}$ & & & \\
\% GEI & $19 \cdot 1$ & $22 \cdot 0$ & $2 \cdot 02$ \\
g/kg DNDFI & $6 \cdot 4$ & $2 \cdot 7$ & $0 \cdot 26$ \\
VFA & $152 \cdot 0$ & $70 \cdot 0$ & $6 \cdot 47$ \\
$\quad$ Acetate/propionate (A/P) & $3 \cdot 4$ & $2 \cdot 6$ & $0 \cdot 13$ \\
Butyrate (mol \%) & $11 \cdot 6$ & $13 \cdot 7$ & $0 \cdot 74$ \\
Protozoa counts $\left(10^{5} / \mathrm{ml}\right)$ & & & \\
$\quad$ Holotrichs & 0 & $0 \cdot 12$ & $0 \cdot 039$ \\
$\quad$ Entodinomorphs & $4 \cdot 70$ & $16 \cdot 35$ & $1 \cdot 876$ \\
Total & $4 \cdot 70$ & $16 \cdot 47$ & $1 \cdot 873$ \\
\hline \hline
\end{tabular}

* Abbreviations and $\mathrm{CH}_{4}$ emission are the same as in Table 2.
$(P>0.05)$ between the animal species were found in the total counts of protozoa in their forestomachs (Table 4).

\section{Experiment 3: Grazing on birdsfoot trefoil pasture (Lotus)}

Diet quality and voluntary feed intake (VFI)

As in the case of PRG/WC pasture, the quality of the Lotus diet eaten by alpaca was much lower than that eaten by sheep (lower N, but higher NDF contents) (Table 1). The OMD of the alpaca diet was much lower than that of sheep $(0.686$ v. 0.800$)$ (Table 1). The concentration of CT in the diet selected by sheep was about twice that in the diet of alpaca or in the forage on offer (Table 1).

As expected, alpaca were heavier $(P<0.01)$ than sheep (Table 5). However, the VFI of sheep were much higher $(P<0 \cdot 001)$ than those of alpaca (Table 5). For example, per $\mathrm{kg}$ of $\mathrm{LW}^{\mathbf{0} 75}$, the GEI (MJ) and NI (g) of sheep were 3.3 and $4 \cdot 2$ times higher, respectively than those of alpaca.

\section{$\mathrm{CH}_{4}$ emission, forestomach volatile fatty acid (VFA) proportions and protozoa counts}

The $\mathrm{CH}_{4}$ production (g/day) by alpaca was similar $(P>0.05)$ to that of sheep $(19 \cdot 1 \mathrm{v} .22 \cdot 0)$. However, the $\mathrm{CH}_{4}$ yield ( $\%$ GEI) and the rate of $\mathrm{CH}_{4}$ production per $\mathrm{kg}$ DNDFI were much higher $(P<0.001)$ for alpaca than sheep (Table 5).

There was a difference $(P<0 \cdot 001)$ between the animal species in $\mathrm{A} / \mathrm{P}$ ratio $(3 \cdot 4$ v. $2 \cdot 6$; for alpaca and sheep, respectively), and the butyrate proportion $(\mathrm{mol} \%)$ in the forestomach contents of sheep were slightly higher $(P=0.07)$ than those in alpaca (Table 5).

As observed in the other two forages (lucerne hay and $\mathrm{PRG} / \mathrm{WC}$ ), no holotrich protozoa were found in the forestomach contents of alpaca (Table 5) and holotrichs accounted for less than $1.0 \%$ of the total protozoa counts in sheep. Animal species significantly $(P<0.001)$ differed in their counts of entodinomorphs and total numbers of protozoa, with higher values for sheep (Table 5). The total concentration of protozoa $\left(10^{5} / \mathrm{ml}\right)$ in the forestomach of sheep was 3.5 times higher than that in alpaca (Table 5).

\section{DISCUSSION}

\section{Diet selection}

Within each of the three forages, the diet selected by the alpaca was of lower quality than that selected by sheep (Table 1). The higher OMD for sheep diets, especially under grazing conditions, might be attributed to the selection of particular plant parts (and plant species), which were higher in $\mathrm{N}$ but lower 
in fibre than the forage on offer. Even when fed on lucerne hay, sheep preferred the leafier material, whereas alpaca preferred the stalkier portions. This confirms the feeding preferences observed by Warmington et al. (1989) when llama $\times$ guanaco crosses and sheep were fed on ryegrass straw.

At grazing, the differences between species in diet selection were even greater. On PRG/WC, sheep selected mostly white clover and grass green leaf, whilst on Lotus, which was almost a pure stand, the sheep diet was composed almost entirely of Lotus leaves. In marked contrast, on PRG/WC, the alpaca avoided white clover but they grazed patches of pure grass completely to ground level. On Lotus, alpaca preferred primarily the senescent grass material (weeds), but because of the low availability of this material, Lotus stem and leaf materials were also eaten. The differences between species in selective grazing were very evident in this study and agree with the results from other studies with alpaca and sheep (Sharp et al. 1995) or guanacos and sheep (Bakker et al. 1997; Fraser \& Gordon 1997; Fraser 1998).

\section{Voluntary feed intake}

On all the three forages, VFI was consistently lower $(P<0 \cdot 001)$ in alpaca than in sheep (Tables 2, 4 and 5). This is consistent with a lower forestomach particulate FOR in alpaca (San Martin 1987).

The VFI of alpaca was relatively constant on all the three forages $(38.8,33.5$ and $40.3 \mathrm{~g} \mathrm{DM} / \mathrm{kg}$ $\mathrm{LW}^{0.75}$, on lucerne hay, PRG/WC and Lotus, respectively) (Tables 2, 4 and 5). In contrast, the VFI of sheep was extraordinarily high when they were grazed on Lotus $\left(128.0 \mathrm{~g} \mathrm{DM} / \mathrm{kg} \mathrm{LW}^{0.75}\right)$. Although it is expected that selective grazing under generous herbage allowance would yield highly digestible diets, the estimate of in vitro DMD of 0.787 for sheep grazing Lotus is slightly high compared with in vivo values in the literature (e.g. 0.766; Wang et al. 1994). Thus, the VFI of Lotus by sheep in the present study may have been overestimated because of the higher in vitro DMD used in the calculation.

Waghorn et al. (1997) and Barry \& McNabb (2000) reported that forages containing more than $55 \mathrm{~g} \mathrm{CT}$ per kg DM may depress VFI. However, Douglas et al. (1995) reported a CT concentration of $57 \cdot 3 \mathrm{~g} / \mathrm{kg} \mathrm{DM}$ in the diet of sheep grazing Lotus, but the VFI of Lotus was greater $(P<0.05)$ than that of lucerne or Lotus $\times$ lucerne pastures. Similarly, Terrill et al. $(1992 b)$ reported that grazing sheep had higher $(P<0 \cdot 001)$ DMI on sulla (Hedysarum coronarium; $36 \mathrm{~g} \mathrm{CT} / \mathrm{kg}$ diet $\mathrm{DM}$ ) than on $\mathrm{PRG} / \mathrm{WC}$ pasture $\left(132\right.$ v. $\left.90 \mathrm{~g} / \mathrm{kg} \mathrm{LW}^{0.75}\right)$. The CT concentration in sheep diets determined in the present study was relatively low, $43.6 \mathrm{~g} / \mathrm{kg} \mathrm{DM}$ (Table 1). Thus, a depressing effect of CT in Lotus on VFI probably did not occur in this study.
The lowest intake recorded in the literature for alpaca was $28.8 \mathrm{~g} \mathrm{OM} / \mathrm{kg} \mathrm{LW}^{0.75}$ for ryegrass hay (Reiner et al. 1987), but the animals lost weight. In the present study alpaca maintained their LW with an average OMI of $34 \mathrm{~g} / \mathrm{kg} \mathrm{LW}^{\mathbf{0} 75}$, whereas sheep gained $\mathrm{LW}$ with an average OMI of $82 \cdot 5 \mathrm{~g} / \mathrm{kg} \mathrm{LW}^{0.75}$.

\section{$\mathrm{CH}_{4}$ emission, forestomach volatile fatty acid (VFA) proportions and protozoa counts}

Weather conditions showed little variation throughout this study and were unlikely to influence the $\mathrm{CH}_{4}$ emission of the animal species. Mean ( \pm s.D.) daily maximum and minimum temperatures $\left({ }^{\circ} \mathrm{C}\right)$ and relative humidity (\%) during Experiments 1, 2 and 3 were $18 \cdot 2( \pm 2 \cdot 55), 9 \cdot 1( \pm 3 \cdot 8)$ and $89 \cdot 0( \pm 8 \cdot 39)$; $19 \cdot 8( \pm 2 \cdot 94), 11 \cdot 1( \pm 3 \cdot 6)$ and $87.9( \pm 7 \cdot 44) ; 19 \cdot 1$ $( \pm 2 \cdot 23), 10 \cdot 8( \pm 3 \cdot 62)$ and $77 \cdot 5( \pm 9 \cdot 18)$, respectively.

Interpretation of the differences between animal species in $\mathrm{CH}_{4}$ emission (Tables 2, 4 and 5) was complicated because these effects were confounded with those of the chemical composition of the diets eaten (Table 1) and VFI (Tables 2, 4 and 5).

Mean $\mathrm{CH}_{4}$ productions (g/day) by sheep were within the range reported in the literature (Blaxter \& Clapperton 1965; Pelchen \& Peters 1998; Ulyatt et al. 1999). However, the $\mathrm{CH}_{4}$ yields (\% GEI) of sheep in this study were relatively lower than those reported in the literature (Pelchen \& Peters 1998), which might be attributed to the effects of the ad libitum feeding (Blaxter \& Clapperton 1965). In addition, the tracer technique used for $\mathrm{CH}_{4}$ measurement, produces slightly lower $\mathrm{CH}_{4}$ values (Johnson et al. 1994b; McCaughey et al. 1999), but relatively higher variation (Pinares-Patiño 2000) compared with indirect calorimetry. Similarly, the $\mathrm{CH}_{4}$ yield of alpaca on lucerne hay $(5 \cdot 1 \%)$ (Table 2$)$ was much lower than those (range $6 \cdot 0-8 \cdot 3 \%$ ) reported for llamas fed on mixed diets (Schneider et al. 1974; Carmean et al. 1992). No other reports were found in the literature of $\mathrm{CH}_{4}$ emission by SAC or from animals grazing on $\mathrm{CT}$-containing forages.

$\mathrm{On}$ all the three forages the $\mathrm{CH}_{4}$ production ( $g$ /day) by sheep were slightly higher (significant only on PRG/WC) than those by alpaca (Tables 2,4 and 5). This can be attributed to the higher $(P<0.001)$ absolute DMI (per head, g/day) observed in sheep than in alpaca. On the other hand, except on lucerne hay (Table 2), the $\mathrm{CH}_{4}$ yields ( $\%$ GEI) were significantly lower $(P<0.05)$ in sheep than in alpaca. The latter is in agreement with the earlier findings by Blaxter \& Clapperton (1965) that $\mathrm{CH}_{4}$ yield decreases with increasing feed intake (relative to maintenance requirements) and with increasing diet digestibility.

Within animal species, GEI per $\mathrm{kg} \mathrm{LW}^{0.75}$ on lucerne hay and PRG/WC was relatively similar $(0 \cdot 74$ and 0.61 MJ for alpaca, and 1.36 and 1.32 MJ for sheep) (Tables 2 and 4). Despite that, the $\mathrm{CH}_{4}$ yields 


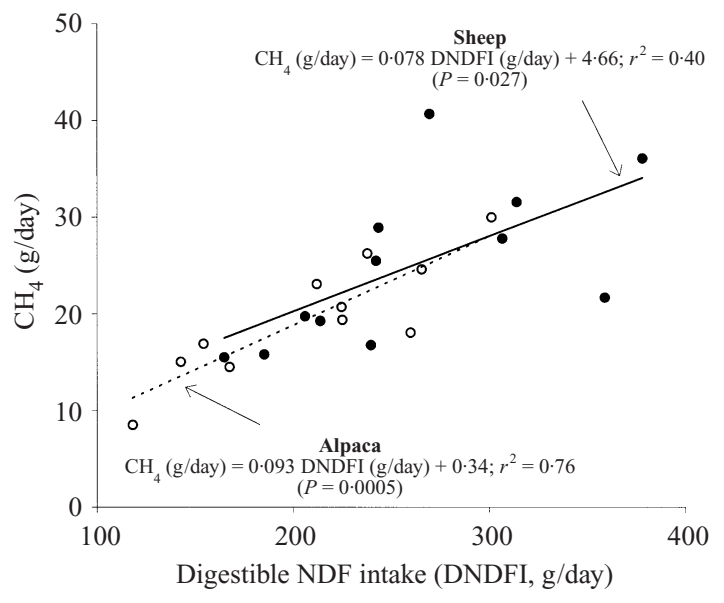

Fig. 1. Relationship between digestible neutral detergent fibre intake (DNDFI, g/day) and $\mathrm{CH}_{4}$ production $(\mathrm{g} /$ day) for alpaca $(\bigcirc)$ and sheep $(\boldsymbol{O})$, when data for lucerne hay and perennial ryegrass/white clover pasture $(\mathrm{PRG} / \mathrm{WC})$ were pooled within animal species.

(\% GEI) of both animal species on PRG/WC were higher than those observed on lucerne hay $(9 \cdot 4 v .5 \cdot 1$ in alpaca; 7.5 v. 4.7 in sheep) (Tables 2 and 4), but a positive relationship between the acetate/propionate (A/P) ratio in the forestomach fluid and $\mathrm{CH}_{4}$ yield (Demeyer \& van Nevel 1975) was not evident between these forages (Tables 2 and 4). On the other hand, in both animal species, the intakes of digestible NDF (DNDFI, g/day) on PRG/WC were higher $(P<0 \cdot 001)$ than those on lucerne hay $(240 \cdot 1 v \cdot 161 \cdot 5$ in alpaca and $311.8 v$ v. 208.7 in sheep; not tabulated). Thus, the higher $\mathrm{CH}_{4}$ yields observed on PRG/WC (both in sheep and alpaca) may be attributed to the increased DNDFI, which is rich in the most methanogenic carbohydrates (cellulose and hemicellulose) (Moe \& Tyrrell 1980).

The rate of $\mathrm{CH}_{4}$ production per unit of DNDFI (g/kg DNDFI) did not differ $(P>0 \cdot 05)$ between animal species either on lucerne hay (Table 2), or PRG/ WC (Table 4), which is in agreement with the concept that $\mathrm{CH}_{4}$ production is mainly a function of cell wall digestion (Moe \& Tyrrell 1980). In fact, when data for lucerne hay and PRG/WC were pooled within animal species, the only intake variable significantly related to $\mathrm{CH}_{4}$ production (g/day) was DNDFI (g/day). The relationship between DNDFI and $\mathrm{CH}_{4}$ production was stronger in alpaca $\left(r^{2}=0.76\right)$ than in sheep $\left(r^{2}=0 \cdot 40\right)$ (Fig. 1), which suggests that the digestion of other feed constituents was also important for the $\mathrm{CH}_{4}$ production in sheep. Nevertheless, neither gradients nor the intercepts of these regression lines were significantly different $(P>0 \cdot 05)$ from each other.

It has been documented (Fraser \& Gordon 1997) that SAC strongly avoid dicotyledonous plants and it was observed in the present study that alpaca primarily ate dead and senescent material when grazed on Lotus pasture. Therefore, the lower NDF digestibility in alpaca on Lotus compared with that on lucerne hay $(0.384$ v. 0.478$)$ may be attributed to the nature of the diet, rather than to any effect of CT on cellulolysis (Foley et al. 1999).

The depressed $\mathrm{CH}_{4}$ yield ( $\%$ GEI) by sheep on Lotus $(2 \cdot 7 \%)$ agrees with earlier observations by Waghorn (1996), who found that sheep fed indoors on Lotus pedunculatus ( $80 \mathrm{~g} \mathrm{CT} / \mathrm{kg} \mathrm{DM})$ yielded less $\mathrm{CH}_{4}$ than when fed on perennial ryegrass or lucerne pastures $(3 \cdot 9,6 \cdot 2$ and $5 \cdot 7 \%$ GEI, respectively). Similar responses were also observed when dairy cows were fed silages of Lotus pedunculatus or perennial ryegrass (Woodward et al. 2001). In addition, other in vitro studies have also found depressing effects on $\mathrm{CH}_{4}$ production of other CT-containing plant species such as Mangifera indica (Finger et al. 1998) and sainfoin (Onobrychis viciifolia) (McMahon et al. 1999).

The depressed $\mathrm{CH}_{4}$ yield by sheep fed Lotus cannot entirely be attributed to the effects of their high intakes (Table 5) of high quality diets (Table 1) (Blaxter \& Clapperton 1965), but probably also represents the action of some compound(s) in Lotus. It is recognized (Foley et al. 1999) that if tannins are present in a plant, then non-tannin phenolics are also present. Thus, whether CT or other compounds in Lotus contributed to the lower $\mathrm{CH}_{4}$ yield observed in sheep remains to be determined, together with its mechanism of action.

The protozoal population in sheep grazing Lotus was four times higher than that on the other two forages, which is in agreement with similar observations when sheep were grazed on sulla (Terrill et al. $1992 b$ ). The reasons for the increased ciliate numbers on Lotus are not clear. Terrill et al. (1992 b) suggested that the high contents of readily fermentable carbohydrates in sulla favoured protozoa growth, whereas CT did not have an adverse effect on it. The absence of holotrichs in the forestomach contents of camelids (Jouany 2000) is confirmed by the present study in alpaca (Tables 2, 4 and 5) and possibly it is due to the nature of their diets (poor in soluble carbohydrates) (Williams \& Coleman 1992).

It is well documented (Jouany \& Lassalas 2000) that, by virtue of inter-species $\mathrm{H}_{2}$ transfer, more $\mathrm{CH}_{4}$ is lost $(\% \mathrm{GEI})$ when protozoa are present in the rumen, and the larger the population of protozoa the greater is the effect. This relationship was confirmed by the present study for data within animal species, when lucerne hay or PRG/WC was fed (Tables 2 and 4). However, reasons for the increased protozoal population, but depressed $\mathrm{CH}_{4}$ yield observed in sheep grazed on Lotus (Table 5) are unknown. Some compound in Lotus may have prevented the occurrence of the physical association between ciliates 
and methanogens necessary for the optimum transfer of $\mathrm{H}_{2}$ (Ushida et al. 1997).

\section{Feed digestibility, energy and $N$ balances, and microbial $N$ supply from the forestomachs in Experiment 1 (fed indoors on lucerne hay)}

Compared with sheep, alpaca digested a significantly greater proportion of the feed NDF and ADF, which confirms the belief that SAC are more efficient in their ability to digest cell walls than sheep (San Martin \& Bryant 1989; Lemosquet et al. 1996; Dulphy et al. 1997). The mechanism for this greater efficiency was attributed to the low fractional outflow rate (FOR) of feed particles from their forestomach (Lemosquet et al. 1996; Dulphy et al. 1997), which would also explain in part the lower VFI by alpaca observed in this and other studies with SAC (San Martin \& Bryant 1989; Lemosquet et al. 1996).

When energy losses were partitioned, as a percentage of GEI (Table 3), there was no difference between the alpaca and sheep in the energy loss in $\mathrm{CH}_{4}$, but alpaca had lower $(P<0.01)$ losses of urinary energy than sheep. The availability of metabolizable energy (ME, \% GEI) did not differ $(P=0 \cdot 12)$ between animal species (Table 3). Carmean et al. (1992) determined that llamas required $0.353 \mathrm{MJ} \mathrm{ME} / \mathrm{kg}$ $\mathrm{LW}^{\mathbf{0} \cdot 75}$ for maintenance, which is similar to the $0.392 \mathrm{MJ} \mathrm{ME} / \mathrm{kg} \mathrm{LW}^{\mathbf{0} 75}$ eaten by the alpaca in the present study while they maintained their LW.

No differences were found between alpaca and sheep in partition of $\mathrm{N}$ (Table 3), which disagrees with previous findings that SAC are more efficient in conserving N (Warmington et al. 1989; Lemosquet et al. 1996; Dulphy et al. 1997). The latter is probably correct on low $\mathrm{N}$ diets, but not on diets high in $\mathrm{N}$, such as lucerne hay.

In conclusion, observations in the current work are consistent with alpaca having a lower particulate
FOR than the sheep: (1) the chemical compositions of diets selected were more fibrous in alpaca, requiring more time for digestion; (2) VFI was lower in alpaca, reflecting more time spent in the forestomach; and (3) digestibility of cell walls was higher in alpaca, a probable consequence of longer retention times in their forestomach. This, and the fact that alpaca and sheep differed in $\mathrm{CH}_{4}$ yield ( $\left.\% \mathrm{GEI}\right)$, suggest that differences between these species in particulate FOR from their forestomach might have been the underlying physiological mechanism responsible for the differences in $\mathrm{CH}_{4}$ yield (Demeyer \& van Nevel 1975; Okine et al. 1989; Pinares-Patiño et al. 2003). However, since VFI and diet quality also differed between animal species, it was impossible to determine the effect of animal species on $\mathrm{CH}_{4}$ yield independently of the effects of differences in diet quality and intake. The low $\mathrm{CH}_{4}$ yield observed on sheep grazing Lotus deserves further study in order to determine the reasons and mechanisms for that. Finally, the results of this study support the belief that SAC have adapted to the highly fluctuating supply of poor quality forages in the Andes by reducing their intake and decreasing the particulate FOR from their forestomach. Thus, compared with sheep, their higher ability to digest structural carbohydrates is associated with relatively higher $\mathrm{CH}_{4}$ yield.

The authors acknowledge Dr M. Tavendale, who kindly analysed the gas samples. The skilled assistance of I. D. Shelton (AgResearch Grasslands) and J. Purchas (Massey University) is also acknowledged. C. S. Pinares-Patiño was in receipt of a postgraduate scholarship from the New Zealand Ministry of Foreign Affairs and Trade. This research was funded by the New Zealand Foundation for Research, Science and Technology and by the New Zealand Ministry of Agriculture and Fisheries.

\section{REFERENCES}

Bakker, M. L., Gordon, I. J. \& Milne, J. A. (1997). Effects of sward structure on the diet selected by guanacos (Lama guanicoe) and sheep (Ovis aries) grazing a perennial ryegrass-dominated sward. Grass and Forage Science 53, 19-30.

BARry, T. N. \& McNABB, W. C. (2000). The effect of condensed tannins in temperate forages on animal nutrition and productivity. In Tannins in Livestock and Human Nutrition, ACIAR Proceedings No. 92 (Ed. J. D. Brooker), pp. 30-35. Camberra, ACT: Australian Centre for International Agricultural Research.

Blaxter, K. L. \& Clapperton, J. L. (1965). Prediction of the amount of methane produced by ruminants. British Journal of Nutrition 19, 511-522.

Carmean, B. R., Johnson, K. A., Johnson, D. E. \& JoHnson, L. W. (1992). Maintenance energy requirements of llamas. American Journal of Veterinary Research 53, 1696-1698.

Chen, X. B. \& Gomes, M. J. (1992). Estimation of microbial protein supply to sheep and cattle based on urinary excretion of purine derivatives - an overview of the technical details (Occasional Publication). Aberdeen, UK: International Feed Resources Unit, Rowett Research Institute.

Demeyer, D. I. \& van Nevel, C. J. (1975). Methanogenesis, an integrated part of carbohydrate fermentation, and its control. In Digestion and Metabolism in the Ruminant, Proceedings of the 4th International Symposium on Ruminant Physiology (Eds I. W. McDonald \& A. C. I. Warner), pp. 366-382. Armidale, Australia: The University of New England Publishing Unit.

Domingue, B. M. F., Dellow, D. W. \& Barry, T. N. (1991). Voluntary intake and rumen digestion of a low 
quality roughage by goats and sheep. Journal of Agricultural Science, Cambridge 117, 111-120.

Douglas, G. B., Wang, Y., Waghorn, G. C., Barry, T. N., Purchas, R. W., Foote, A. G. \& Wilson, G. F. (1995). Live weight gain and wool production of sheep grazing Lotus corniculatus and lucerne (Medicago sativa). New Zealand Journal of Agricultural Research 38, 95-104.

Dulphy, J. P., Dardillat, C., Jailler, M. \& Ballet, J. M. (1997). Comparative study of forestomach digestion in llamas and sheep. Reproduction, Nutrition, Development 37, 709-725.

Dulphy, J. P., Dardillat, C., Jailler, M. \& Jouany, J. P. (1994). Comparison of the intake and digestibility of different diets in llamas and sheep: a preliminary study. Annales of Zootechnia 43, 379-387.

Finger, T., Hayler, R., Steingaß, H. \& Drochner, W. (1998). Effect of various feedstuffs rich in fat or tannin content on rumen methanogenesis in vitro-using the Hohenheim gas test (HGT). Proceedings of the British Society of Animal Science, p. 225. Scarborough, UK: British Society of Animal Science.

Foley, W. J., Iason, G. R. \& McArthur, C. (1999). Role of plant secondary metabolites in the nutritional ecology of mammalian herbivores: how far have we come in 25 years? In Nutritional Ecology of Herbivores, Proceedings of the Vth International Symposium on the Nutrition of Herbivores (Eds H. G. Jung \& G. C. Fahey), pp. 130-209. Savoy, Ill: American Society of Animal Science.

Fraser, M. D. (1998). Diet composition of guanacos (Lama guanicoe) and sheep (Ovis aries) grazing in grasslands communities typical of UK uplands. Small Ruminant Research 29, 201-212.

Fraser, M. D. \& Gordon, I. J. (1997). The diets of goats, red deer and South American camelids feeding on three contrasting Scottish upland vegetation communities. Journal of Applied Ecology 34, 668-686.

Goering, H. K. \& van Soest, P. J. (1970). Forage fiber analysis. Agricultural Handbook 379, 1-20.

Heller, R., Cercasov, V. \& Engelhardt, W. V. (1986). Retention of fluid and particles in the digestive tract of the llama (Lama guanacoe F. glama). Comparative Biochemistry and Physiology 83A, 687-691.

Hodgson, J. (1990). Grazing Management, Science into Practice. Harlow: Longman Scientific and Technical.

Hoskin, S. O., Stafford, K. J. \& Barry, T. N. (1995). Digestion, rumen fermentation and chewing behaviour of red deer fed fresh chicory and perennial ryegrass. Journal of Agricultural Science, Cambridge 124, 289-295.

Johnson, K., Huyler, M., Westberg, H., Lamb, B. \& Zimmerman, P. (1994a). Measurement of methane emissions from ruminant livestock using a $\mathrm{SF}_{6}$ tracer technique. Environmental Science and Technology 28, 359-362.

Johnson, K. A., Huyler, M. T., Westberg, H. H., Lamb, B. K. \& Zimmerman, P. (1994b). Measurement of methane emissions from ruminant livestock using a sulfur hexafluoride tracer technique. In Energy Metabolism of Farm Animals, Proceedings of the 13th Symposium (Ed. J. F. Aguilera), pp. 335-338. Mojacar, Spain: Servicio de Publicaciones, Consejo Superior de Investigaciones Cientificas.

Jouany, J. P. (2000). La digestion chez les camelides; comparison avec les ruminants. Productions Animales 13, $165-176$.
Jouany, J. P. \& Lassalas, B. (2000). Effect of protozoa on methane production in the rumen; consequences on carbon and hydrogen distribution among the other end products of fermentation. In Methane Mitigation, Proceedings of Second International Conference, pp. 121-123. Novosibirsk, Russia: U.S. Environmental Protection Agency and Siberian Branch of Russian Academy of Sciences.

Lassey, K. R., Ulyatt, M. J., Martin, R. J., Walker, C. F. \& Shelton, I. D. (1997). Methane emissions measured directly from grazing livestock in New Zealand. Atmospheric Environment 31, 2905-2914.

Lemosquet, S., Dardillat, C., Jailler, M. \& Dulphy, J. P. (1996). Voluntary intake and gastric digestion of two hays by llamas and sheep: influence of concentrate supplementation. Journal of Agricultural Science, Cambridge 127, 539-548.

McCaughey, W. P., Wittenberg, K. \& Corrigan, D. (1999). Impact of pasture type on methane production by lactating beef cows. Canadian Journal of Animal Science 79, 221-226.

McMahon, L. R., Majak, W., McAllister, T. A., Hall, J. W., Jones, G. A., Popp, J. D. \& Cheng, K.-J. (1999). Effect of sainfoin on in vitro digestion of fresh alfalfa and bloat in steers. Canadian Journal of Animal Science 79, 203-212.

Milne, J. A., MacRae, J. C., Spence, A. M. \& Wilson, S. (1978). A comparison of the voluntary intake and digestion of a range of forages at different times of the year by the sheep and the red deer (Cervus elaphus). British Journal of Nutrition 40, 347-357.

Moe, P. W. \& Tyrrell, H. F. (1980). Methane production in dairy cows. In Energy Metabolism, Proceedings of the 8th Symposium in Energy Metabolism (Ed. L. E. Mount), pp. 59-62. London: Butterworths.

Okine, E. K., Mathison, G. W. \& Hardin, R. T. (1989). Effects of changes in frequency of reticular contractions on fluid and particulate passage rates in cattle. Journal of Animal Science 67, 3388-3396.

Pelchen, A. \& Peters, K. J. (1998). Methane emissions from sheep. Small Ruminant Research 27, 137-150.

Pinares-Patiño, C. S. (2000). Methane Emission from Forage-fed Sheep, a Study of Variation Between Animals. Ph.D. thesis, Massey University, Palmerston North, New Zealand.

Pinares-Patiño, C. S., Ulyatt, M. J., Lassey, K. R., Barry, T. N. \& Holmes, C. W. (2003). Rumen function and digestion parameters associated with differences between sheep in methane emissions when fed chaffed lucerne hay. Journal of Agricultural Science, Cambridge 140, 205-214.

RagGi, L. A. \& Ferrando, G. (1998). Advances in adaptation and physiology of South American camelids. Avances en Ciencias Veterinarias 13, 3-15.

Reiner, R. J., Bryant, F. C., Farfan, R. D. \& Craddock, B. F. (1987). Forage intake of alpacas grazing Andean rangeland in Peru. Journal of Animal Science 64, 868-871.

Roughan, P. G. \& Holland, R. (1977). Predicting in vivo digestibilities of herbages by exhaustive enzymic hydrolysis of cell walls. Journal of the Science of Food and Agriculture 28, 1057-1064.

San Martin, F. (1987). Comparative Forage Selectivity and Nutrition of South American Camelids and Sheep. Ph.D. thesis, Texas Tech University, Lubbock, Texas, USA. 
San Martin, F. \& Bryant, F. C. (1989). Nutrition of domesticated South American llamas and alpacas. Small Ruminant Research 2, 191-216.

SAS $^{\circledR}$ (1985). User's Guide: Statistics (Version 5). Cary, NC: SAS Institute, Inc.

Sharp, P., Knight, T. W. \& Hodgson, J. (1995). Grazing behaviour of alpaca and sheep. Proceedings of the New Zealand Society of Animal Production 55, 183-185.

Schneider, W., Hauffe, R. \& Engelhardt, W. V. (1974). Energie- und stickstoffumsatz beim Lama. In Energy Metabolism of Farm Animals (Eds K. H. Menke, H.-J. Lantzsch \& J. R. Reichl), pp. 127-130. Hohenheim: Universität Hohenheim.

Terrill, T. H., Rowan, A. M., Douglas, G. B. \& Barry, T. N. (1992a). Determination of extractable and bound condensed tannin concentrations in forage plants, protein concentrate meals and cereal grains. Journal of the Science of Food and Agriculture 58, 321-329.

Terrill, T. H., Douglas, G. B., Foote, A. G., Purchas, R. W., Wilson, G. F. \& Barry, T. N. (1992b). Effect of condensed tannins upon body growth, wool growth and rumen metabolism in sheep grazing sulla (Hedysarum coronarium) and perennial pasture. Journal of Agricultural Science, Cambridge 119, 265-273.

Ulyatt, M. J., Baker, S. K., McCrabb, G. J. \& Lassey, K. R. (1999). Accuracy of $\mathrm{SF}_{6}$ tracer technology and alternatives for field measurements. Australian Journal of Agricultural Research 50, 1329-1334.

Ushida, K., Tokura, M., Takenaka, A. \& Itabashi, H. (1997). Ciliate protozoa and ruminal methanogenesis. In Rumen Microbes and Digestive Physiology in Ruminants (Eds R. Odonera, H. Itabashi, K. Ushida, H. Yano \&
Y. Sasaki), pp. 209-220. Tokyo: Japan Scientific Society Press.

Vallenas, A., Cummings, J. F. \& Munnell, J. F. (1971). A gross study of the compartmentalized stomach of the two New World Camelids, the llama and guanaco. Journal of Morphology 134, 339-424.

WaGHorn, G. C. (1996). Condensed tannins and nutrient absorption from the small intestine. In Animal Science Research and Development, Meeting Future Challenges (Ed. L. M. Rode), pp. 175-193. Lethbridge, Alberta: Agriculture and Agri-Food Canada.

Waghorn, G. C., Reed, J. D. \& Ndlovu, L. R. (1997). Condensed tannins and herbivore nutrition. In Proceedings of the XVIII International Grassland Congress, (Session 8), pp. 153-166. Lacombe, AB: Agriculture and Agri-Food Canada.

WAng, Y. X, Waghorn, G. C., Barry, T. N. \& Shelton, I. D. (1994). The effect of condensed tannins in Lotus corniculatus on plasma metabolism of methionine, cystine and inorganic sulphate by sheep. British Journal of Nutrition 72, 923-935.

Warmington, B. G., Wilson, G. F. \& Barry, T. N. (1989). Voluntary intake and digestion of ryegrass straw by llama $\times$ guanaco crossbreds and sheep. Journal of Agricultural Science, Cambridge 113, 87-91.

Williams, A. G. \& Coleman, G. S. (1992). The Rumen Protozoa. New York: Springer-Verlag.

Woodward, S. L., Waghorn, G. C., Ulyatt, M. J. \& LASSEY, K. R. (2001). Early indications that feeding Lotus will reduce methane emissions from ruminants. Proceedings of the New Zealand Society of Animal Production 61, 23-26. 
Methane emission by alpaca and sheep fed

on lucerne hay or grazed on pastures of perennial ryegrass/white clover or birdsfoot trefoil

Pinares-Patiño, C. S.

2003

http://hdl.handle.net/10179/9680

22/04/2023 - Downloaded from MASSEY RESEARCH ONLINE 